\title{
Measuring the Concentration of Insurance sector - the Case of Southeastern European Countries
}

\begin{abstract}
Maja DIMIĆ ${ }^{1}$, Lidija BARJAKTAROVIĆ ${ }^{2}$, Olja ARSENIJEVIĆ ${ }^{1}$, Polona ŠPRAJC $^{3}$, Janez ŽIROVNIK ${ }^{3}$
\end{abstract}
\author{
${ }^{1}$ University Union Nikola Tesla, Faculty of Business Studies and Law, Staro sajmište 29, 11000 Belgrade, Serbia \\ maja.dimic@fpsp.edu.rs, Serbia, olja.arsenijevic@fpsp.edu.rs
}

${ }^{2}$ University Singidunum, Faculty of Business Belgrade, 32 Danijelova St., Belgrade, Serbia Ibarjaktarovic@singidunum.ac.rs

${ }^{3}$ University of Maribor, Faculty of Organizational Science, Kidriceva cesta 55a, 4000 Kranj, Slovenia polona.sprajc@fov.uni-mb.si, janez.zirovnik@guest.um.si

\begin{abstract}
Background and purpose: The goal of the paper is to determine the level of concentration in the insurance sector in the following eight countries of South and Eastern Europe: Serbia, Croatia, Bosnia and Herzegovina, Montenegro, Former Yugoslav Republic of Macedonia, Romania, Bulgaria and Albania in the period from 2007 to 2012.

Design/Methodology/Approach: In this context, the analysed indicators of concentration were the market share of the four leading financial institutions (CR4), the Herfindahl-Hirschman Index (HHI), the coefficient of entropy (E), the coefficient of relative entropy (RE) and Gini coefficient (G).

Results: The study showed that the insurance sectors in the analysed countries are highly concentrated on average (according to CR4 indicator), medium concentrated (according to $\mathrm{HHI}$ ) with high levels of inequality of distribution of market shares between individual participants (in terms of G coefficient), and in the zone of relative uniformity and equality of business entities (according to RE coefficient). The research results point out that the existence of different levels of correlation between the analysed indicators of concentration in the insurance sector, which confirms the conclusion that, in order to obtain relevant and quality conclusions about the level of concentration, it is necessary to review and analyse several indicators of concentration integrally.

Conclusion: In all observed indicators of concentration in relation with the density level GDP pc move in the zone of very low value, which on the one hand points to the fact that the analysed countries at a relatively similar level of development have significantly different levels of concentration, but also on the fact that some countries although at different levels of development, have similar levels of concentration.
\end{abstract}

Keywords: insurance sector; concentration level; concentration indicators; South-Eastern European countries

\section{Introduction}

The concentration process, as a result of the strong global economy, leads to the development of relatively large companies, which become economically stronger and have the ability to obtain a more favourable position in the market. The concept of concentration in the financial sector is defined as a form of connecting institutions under a common control system, which consequently creates a certain level of economic community among them that did not exist before. Hawkins and Mihaljek (2001) identify the following motives for financial institution mergers:

1. Cost benefits (economies of scale, organisational efficiency, cost of funding, risk diversification, economising on capital);

2. Economic conditions (mergers after crises or during

Received: July 14, 2017; revised: December 21, 2017; accepted: December 4, 2017 
an upswing of the business cycle); and other motives (private managerial benefits, defence against takeovers, etc.).

The goal of the paper is to determine the level of concentration in the insurance sector in the eight selected countries of South and Eastern Europe (SEE): Serbia - SRB, Croatia - CRO, Bosnia and Herzegovina- BiH, Montenegro - MNE, Former Yugoslav Republic of Macedonia - FYRM, Romania - ROU, Bulgaria - BGR and AlbaniaALB, with the comparable level of gross domestic product /GDP/ (CRO is exception) within the period 2007-2012.

There are several reasons for analysing this time period. Firstly, the beginning of the analysed period is marked by the appearance and later with the expansion of the economic crisis spilled over from the United States of America (USA) to Europe. Secondly, in this economic environment, it is interesting to examine the approach in which the financial institutions, in particular insurance companies which represent the focus group, are going to fight with the negative effects of the crisis: will they increase their market shares in the countries in the region by opening new branches or will they focus on mergers and/ or acquisitions in order to maintain the leading position in the market? Thirdly, will the mergers of financial institution lead to a reduction of the total number of institutions operating in the region as well as increase a concentration level? The analysed period of six years was long enough to give an overview and evaluate changes related to the formation of appropriate control balance in certain markets. The research may also help in understanding the trends of concentration in the insurance sector in the future. The authors begin with the following assumptions and check the validity of the hypothetical statement in the empirical research:

(H1): There is a high level of concentration in insurance sector in SEE region. Indicators: indicators of concentration: market share of the four leading financial institutions (CR4), Herfindahl-Hirschman Index (HHI), Gini coefficient (G), coefficient of entropy (E), and the coefficient of relative entropy (RE) based on development criteria in insurance sector: total earned premiums, total earned non-life premiums and total earned life premiums.

(H2): There are significant differences in the level of correlation between each of the analysed indicators of concentration in the insurance sector in selected countries of SEE. Indicators: indicators of concentration: CR4, HHI, $\mathrm{G}, \mathrm{E}, \mathrm{RE}$ based on development criteria in insurance sector: total earned premiums, total earned non-life premiums and total earned life premiums.

(H3): The level of concentration in the insurance sector is poorly correlated with the level of economic development in the analysed SEE countries. Indicators: indicators of concentration: CR4, HHI, G, E, RE based on development criteria in insurance sector: total earned premiums, total earned non-life premiums, total earned life premiums and GDP per capita.

Empirical and scientific studies in SEE region confirm that a market structure with its characteristics affects the behaviour of financial institutions, primarily the banking sector: their performance and mostly profitability (Kundid et al., 2011; Ćurak et al., 2012; Athanasoglou et al., 2006). When it comes to the level of concentration in insurance sector in the region, Njegomir and Stojić (2011) are pioneers in analysing this market structure. The authors (Njegomir, \& Stojić, 2011) examined the segment of nonlife insurance in 11 countries in Eastern Europe in the period 2004-2008. The results of the model indicate that a low level of concentration has a minor, but positive impact on profitability. However, as the market concentration increases on one side, it reduces the effect on profitability on the other side. So far conducted scientific and empirical research about the level of concentration in the insurance sector is mostly focused on analysing one of the SEE countries or their comparison with EU member states, as well as only individual indicators of concentration, usually HHI and CR4. The aim of the paper is to use multiple indicators of concentration as well as to determine and explain valid results of an empirical analysis of the concentration level in selected SEE countries. Furthermore, the projected methodological instruments and the concrete results of empirical research could have broader applications in finding adequate solutions against unwelcome market structures in the insurance sector.

For the empirical research, authors have used the following resources for the period 2007-2012:

- Serbia: National bank of Serbia (Insurance sector reports and Annual reports)

- Croatia: Croatian insurance bureau (Insurance market in the Republic of Croatia)

- Bosnia and Herzegovina: Insurance supervision agency (Statistics of insurance market)

- Montenegro: Insurance supervision agency (Report on insurance market in Montenegro)

- Former Yugoslav Republic of Macedonia: Insurance supervision agency (Report on the scope and content of the insurance operations)

- Romania: Romanian Insurance Supervisory Commission (Annual report on the activity performed and the insurance market development)

- Bulgaria: Financial Supervision Commission (Statistics: Markets - non-life insurance companies, Life insurance companies)

- Albania: Albanian Financial Supervisory Authority (Insurance geography statistical report) 


\section{Literature review}

Concentration is defined as a measure of subject participation in cumulative sales, assets or market share and it is usually determined by the number of companies in an industry and by their relative size (Zingales et al., 2003). Measurement of concentration in the banking sector is very specific due to the problem of identification of products and services traded (Miljković et al, 2013). In theory there are two directions to determine the mentioned relation, i.e. authors who proved and authors who didn't prove that relation. In the first group there are authors who believe that concentration and competitiveness are in negative relation, i.e. high level of concentration leads to a decrease of market competitiveness. Chamberlain, Hall and Hitch, and Sweezy showed that oligopoly markets can limit competitiveness (Kraft, 2007). Bikker and Haff (2001) proved on the basis of empirical research that there is high level of correlation between HH index and concentration ratio.

We should not neglect the fact that foreign investors, when entering a new insurance market, are faced with a series of containing factors: undeveloped financial market, limits in presentation of new funds, big founding stakes in relation to European Union, low insurance culture and lack of confidence of the citizens in insurance institution. In addition, the inflow of foreign investments also depends on financial stability of a country and its credit rating, inflation and exchange rate movement (Dimić, 2015). The process of privatization of insurance companies in the region was carried out differently in the analyzed region. In that way, Croatia and Serbia have carefully entered this process and retained the ownership of the national insurance companies, which was not the case in Montenegro and Macedonia (Dimić, 2015).

Very often the issue of justification of foreign investors' entrance to insurance market in financially undeveloped countries is brought about (Dimić et al, 2017). According to previous studies, there are several key advantages: development of life insurance, improvement of corporate management and risk management in business, improvement of service quality, introduction of new and high quality service packages, increase of health competition, strengthening of transparency in business, transfer of technological and managerial know-how, external funding sources.

In scientific references there are divided attitudes when it comes to ownership transformation in financial sector. Thus one group of authors believe that high share of foreign ownership in total balance sum and insurance premium (or capital) can represent a great problem to the development of economy in the analyzed region of SEE. In addition to the growth of concentration level caused by merging of financial institutions, it is required to monitor the concentration level of each financial institution individually, as well as „mother" companies that affect the business policy of financial institutions in region through the administration and supervisory board. On the other hand, group of authors concludes that entrance of foreign insurance companies to financial market of the analyzed region has a positive effect on competition. In that context, entrance of foreign financial investors increases competition pressures (because it carries along new technologies and new knowledge) to the domestic financial system. Taking that into consideration, it is no wonder that in the last twenty years the share of foreign ownership in insurance sector was increased in the region analyzed. Although the increase of market concentration is the most frequent sign of dropping intensity of competitiveness, some studies (Beck et al, 2003) point out that greater presence of foreign financial mediators mitigates negative aspects of greater market concentration.

\section{Explaining the research method}

Empirical research of concentration level in the insurance market is based on appropriate criteria of the development in the insurance sectors: total earned premiums, total earned non-life premiums and total earned life premiums. In this context, the mention criteria of the development are used as inputs for calculating the level of concentration: CR4, HHI, E, RE, G (Table 1).

An empirical analysis of the concentration level in the insurance sector in the SEE region is based on the available data which are processed by using statistical software packages and tools: Microsoft Excel and the Statistical Package for the Social Sciences (SPSS). Data analysis aims to determine the level of each indicator of concentration in the insurance sector in the analysed countries as well as to calculate their variability in the period 20072012. At this point, empirical research was carried out in three steps:

1. Calculation of concentration indicators in the analysed countries by using three criteria of development in the insurance sectors as inputs;

2. Determination of the average value of the concentration indicator in each country in the analysed period as well as the weighted average value of the concentration indicator for the region in each one year. Having in mind that the different levels of total premiums, as well as premiums of life and non-life insurance, occur in the analysed countries, the weights are used as the share of indicators' total.

3. Determining statistical measures of variability (level of variability of the concentration indicators) by using the coefficient of variation as a relative measure of variability. In this context, authors analysed: dynamic changes (variability) of concentration levels by each country in the period 2007-2012 as well as changes (variability) of concentration levels between the countries analysed in each year. 
Table 1: Market concentration indicators. Source: Dumićić et al. 2012; Ljubaj, 2005

\begin{tabular}{|c|c|c|}
\hline Indicator & $\begin{array}{l}\text { Marks and inter- } \\
\text { val value }\end{array}$ & Explenation of indicators' value \\
\hline Concentration ratio & $1 / \mathrm{n} \leq \mathrm{C}_{\mathrm{r}} \leq 1$ & $\begin{array}{l}\text { Index value is closer to } 0 \text { when tehre are a large number of firms with } \\
\text { the similar market share. Index value is closer to } 1 \text { when the sum of " } n \text { " } \\
\text { firms create a market. }\end{array}$ \\
\hline Herfindahl-Hirschman index & $1 / \mathrm{n} \leq \mathrm{HHI} \leq 1$ & $\begin{array}{l}\text { The higger value of indicator create the higher level of concentration. } \\
\text { When the indicator value is } 10.000 \text { there is a monopolistic competition. }\end{array}$ \\
\hline Entropy concentration index & $0 \leq \mathrm{E} \leq \log n$ & $\begin{array}{l}\text { The higher the entropy concentration index, the lower level of concen- } \\
\text { tration is. In the case of a monopolistic competition the index value is } 0 \text {. }\end{array}$ \\
\hline Lorenz curve & - & The higher the coefficient, the more unequal the distribution is. \\
\hline Gini coefficient & $0 \leq \mathrm{G} \leq 1$ & $\begin{array}{l}\text { The higher the coefficient, the higher level of concentration is. In the } \\
\text { case of inequality, the indicator value is } 1 .\end{array}$ \\
\hline
\end{tabular}

Total earned premiums

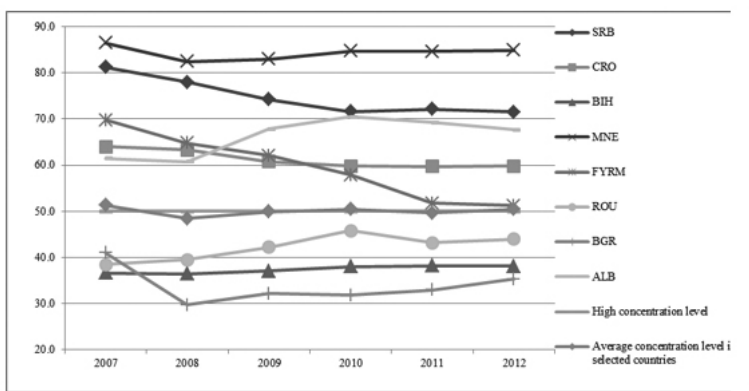

Total earned non-life premiums

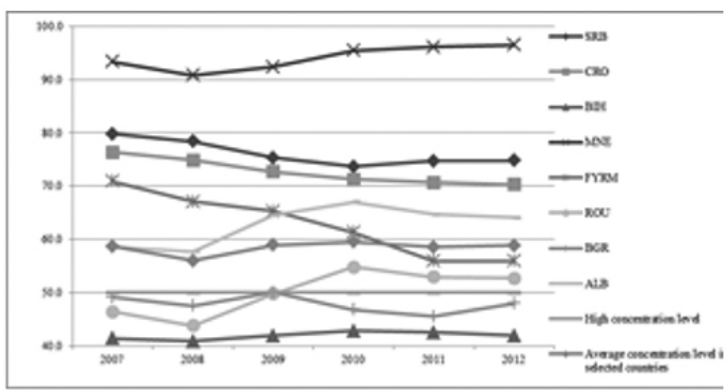

Total earned life premiums

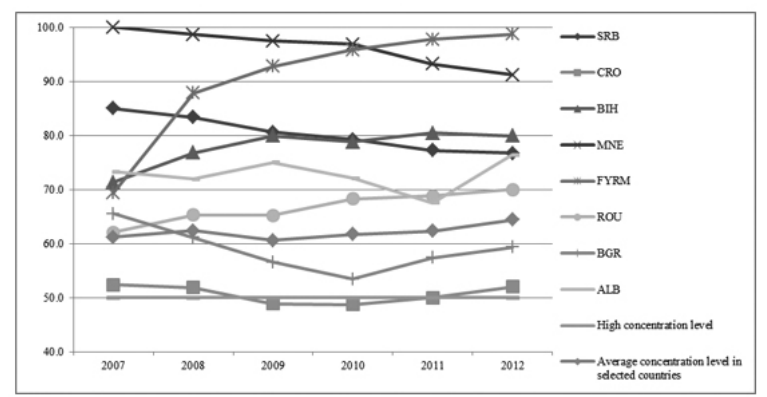

Figure 1: CR4

A particular part of the research relates to the determination of the correlation between indicators of concentration, as well as between indicators of concentration and levels of GDP pc. At this point, Pearson and Spearman correlation coefficients are used. Correlation analysis of individual indicators of concentration in the SEE region in a defined period of time can indicate the extent to which, when assessing real developments and changes, we can rely on a smaller number of indicators (if there is a high correlation level among them) and thus ease research and analysis, or whether in case of absence of significant correlation, we need to focus on the simultaneous analysis of a large number of indicators of concentration. In addition, authors examine whether the country with relatively similar GDP pc have the similar or different levels of concentration in the insurance sector, or whether countries with relatively similar levels of concentration have the same or different GDP pc, by using Spearman correlation coefficient. 


\section{Empirical research}

\subsection{Concentration rato - CR4}

CR4 average values show that the analysed countries in the SEE region recorded a high level of concentration (Figure1). According to the criteria of the total earned premiums the concentration level is on the border line of $50 \%$, while in the case of premiums of non-life and life insurance concentration level is $60 \%$.

According to total earned premiums $\mathrm{BiH}, \mathrm{BLG}$ and ROU are bellow the line of high concnetration level (Figure 1). The highest concentration level is recorded in MNE and SRB, $86 \%$ and $81 \%$, respectively, while the concnetration level in other selected coutries were between $60 \%$ and $70 \%$, which is still 10 to 20 procentage points above the line of moderately concentrated market.

Situation is similar according to total earned non-life premiums. It is significant to underline that 4 insurance companies in MNE (total of 5, i.e. 7 in 2008 and 6 in 2009, only non-life insurance) have the market share of $94 \%$. High levels of concentration appear in SRB and CRO, where CR4 indicator is over $70 \%$. On the other hand, the lowest levels of concentration are in $\mathrm{BiH}$ and $\mathrm{BLG}, 42 \%$ and $48 \%$, respectivly.

According to the total earned life premiums, CR4 indicator is above the line of high concentration in all analyzed countries (with the exception of CRO, where CR4 is approximetely $50 \%$ ). Similarly to the previously mentioned cases, the highest levels of concentration exists in MNE $(96 \%)$ and FYRM (90\%). CR4 indicator was between $60 \%$ and $80 \%$ in other analyzed countries. There were no significant variations by country in the level of concentration according to CR4 indicator.

The major coefficients of variation of CR4 are recorded in FYRM (in terms of total earned premiums and total earned life premiums), while the minimum coefficients of variation are in the $\mathrm{MNE}$ and $\mathrm{BiH}$ insurance market, observed by countries. Variations between countries are several times higher and illustrate that the coefficients of variation of CR4 are major according to the criteria of total earned non-life premium (about 7 percentage point), with the highest concentration changes during the period 20082009.

\subsection{Herfindahl-Hirschman index}

When it comes to the concentration level analysis based on $\mathrm{HHI}$ in the insurance market in the analysed region, it can be concluded that this segment of the financial market, with an average concentration values of total earned premiums, total earned non-life premiums and total life premiums of $1,100,1,350$ and 1,460 points respectively, is located in group of moderately concentrated market (Figure 2).

According to total earned premiums criteria, the highest level of concentration was in MNE (above 4.000 points in 2007 and 2008) measured by HHI. In addition, SRB was in the group of highly concentrated markets with 2.000 points in initial two years. In the following years, HHI decreased and in the end of 2012 was 1.600 points in SRB. On the other hand, the lowest level of concentration is measured in $\mathrm{BiH}, \mathrm{ROU}$ and BLG (lower than 1.100 points).

In terms of total earned non-life premiums criteria, the highest concentratded markets were MNE (with average concentratin level of 4.150 points), CRO (with average 1.973 points) and SRB (with average 1.948 points), while other analysed countries were below the line of high concentrated markets, entering the group of moderately concenrtated market, and emphasizing $\mathrm{BiH}$ as a country with the lowest level of concentration (720 points).

Table 2: Coefficients of variation of CR4 (in \%)

\begin{tabular}{|c|c|c|c|c|c|c|c|}
\hline \multicolumn{4}{|c|}{$\begin{array}{l}\text { Coefficients of variation by each country in the period } \\
\qquad 2007-2012\end{array}$} & \multicolumn{4}{|c|}{ Coefficients of variation between countries by each year } \\
\hline Country & $\begin{array}{c}\text { Total } \\
\text { earned } \\
\text { premiums }\end{array}$ & $\begin{array}{l}\text { Total earned non- } \\
\text { life premiums }\end{array}$ & $\begin{array}{l}\text { Total earned } \\
\text { life premiums }\end{array}$ & Year & $\begin{array}{c}\text { Total } \\
\text { earned } \\
\text { premiums }\end{array}$ & $\begin{array}{l}\text { Total earned non- } \\
\text { life premiums }\end{array}$ & $\begin{array}{c}\text { Total } \\
\text { earned life } \\
\text { premiums }\end{array}$ \\
\hline SRB & 5.3 & 3.2 & 4.1 & 2007 & 31.0 & 25.9 & 14.6 \\
\hline CRO & 3.1 & 3.4 & 3.3 & 2008 & 33.0 & 27.3 & 14.8 \\
\hline BIH & 2.1 & 1.7 & 4.4 & 2009 & 28.4 & 20.9 & 18.8 \\
\hline MNE & 1.7 & 2.4 & 3.5 & 2010 & 25.2 & 18.6 & 19.1 \\
\hline FYRM & 2.4 & 9.8 & 12.2 & 2011 & 26.3 & 20.3 & 17.2 \\
\hline ROU & 6.5 & 8.5 & 4.4 & 2012 & 24.8 & 19.7 & 16.4 \\
\hline BLG & 11.7 & 3.4 & 7.1 & & & & \\
\hline ALB & 6.2 & 5.9 & 4.2 & & & & \\
\hline
\end{tabular}




\section{Total earned premiums}

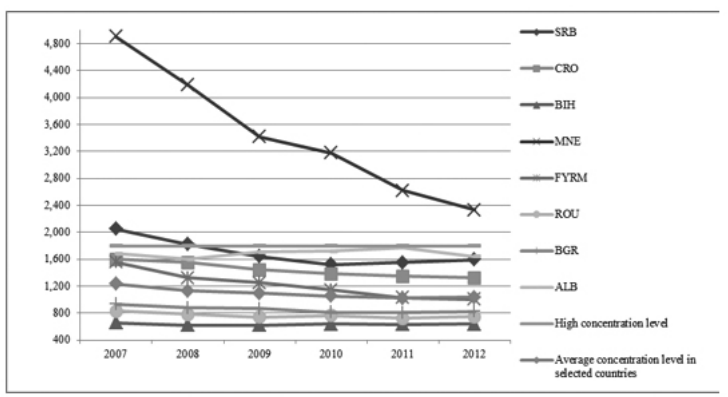

Total earned non- life premiums

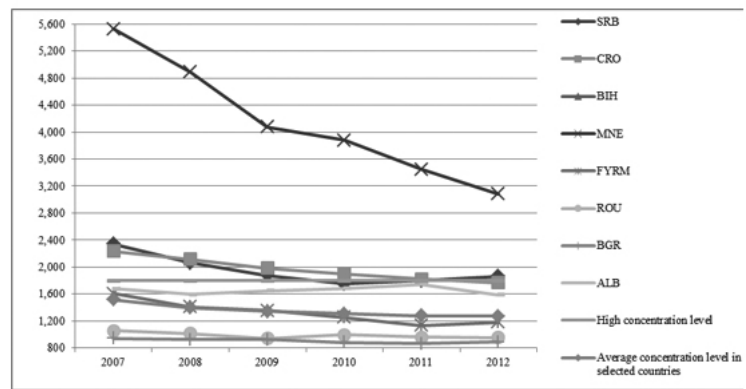

Total earned life premiums

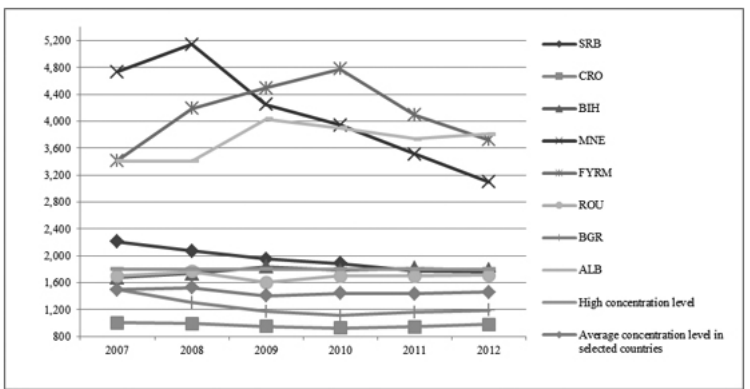

Figure 2: HHI

HHI values for the total earned life premiums criteria show that MNE and FYRM (with the average values of 4.000 points) as well as ALB (with 3.700 points) were highly concentreted markets in the analysed region. On the other side, the CRO insurense market had the lowest level of concentration.

Coefficients of variation of HHI were significantly higher when analysing changes between countries (most evident according to the criterion of non-life insurance premiums).

The highest coefficient values of variation were recorded in the 2007-2009 period, with a declining tendency. If we look inside the country during the period 2007-2012, we can conclude that insurance market in MNE changed most significantly, especially in relation to total earned premiums (28.1\%). Opposite, lowest fluctuations are present in the $\mathrm{BiH}$ insurance market $(1.6 \%$ in non-life insurance premium) in the dynamic model.

\subsection{The coefficient of entropy}

The coefficient of entropy has certain disadvantages when it is used in the comparative analysis in a dynamic context. In a situation, which is typical for this research paper, where there is a particular market (country) in a different period of time (a year) and number of business entities (insurance companies), E coefficient should be adjusted in order to allow comparison between countries as well as different time points (years). In this context, $R E$ is calculated as a ratio of $E$ value and a maximum $E$ value for a given number of entities (expressed as the natural logarithm of the number of insurance companies - $\log _{\mathrm{n}}$ ). Further, the relative distance of concentration ( $R E$ ) is measured with ranges from 0 (highest concentration) to 1 (the lowest concentration). This indicator takes into account differences in the number of business entities in the selected countries and period of time and has an important result corrective of E coefficient. In the case of SRB, E coefficient of total insurance premium in 2012 was 2.22602. If we consider this market structure between the two extremes $\left(0\right.$ and $\left.E=\log _{n}\right)$, respectively, 0 and 3.178 (which is the normal logarithm of the number 24 - insurance companies operating on the Serbian market in 2012), it can be assumed that Serbian insurance market is closer to the upper extreme (3.178). Relative distance of concentration amounts to $0.70(70 \%)$ and indicates that the existing market structure is closer to market share equality. The higher relative distance of concentration indicates lower degree of concentration.

Average values of the RE coefficient in the insurance sector in the analysed countries in the region illustrate the following results: $0.78(78 \%)$ total earned premiums, 0.77 (77\%) total earned non-life premiums and $0.8(80 \%)$ total earned life premiums. If we look at each criteria of development in insurance sector separately, we can conclude that there are no significant differences between them in the analysed period. It can be ascertained that the high av- 
erage value of the RE coefficient leads to the conclusion that the insurance market in the analysed region is closer to a competitive market structure than oligopoly or monopoly. The results presented in the Figure 3, show an increasing trend of stagnation of RE coefficient according to analysed criteria of the development of the insurance sectors.

Four (FYRM, BiH, ALB, BLG) out of eight analysed countries recorded higher values of relative entropy in comparison with the average value, according to the criterion of the total earned premiums and total earned non-life premiums. Additional countries, with recorded amounts below average value of the region, had lower level of relative distance of concentration. In this context, it can be concluded that distribution of market shares have become less equal with greater concentration in these markets.

In regards to total earned life premiums, ALB, BLG and $\mathrm{CRO}$ were in the group with higher values of relative distance than calculated average value of the region. It can be concluded that the CRO and BLG markets are more developed in comparison with Albanian in the segment of

Table 3: Coefficient of variation of HHI (in \%)

\begin{tabular}{|c|c|c|c|c|c|c|c|}
\hline \multicolumn{4}{|c|}{$\begin{array}{l}\text { Coefficients of variation by each country in the peri- } \\
\qquad \begin{array}{l}\text { od } 2007-2012 \\
\end{array}\end{array}$} & \multicolumn{4}{|c|}{ Coefficients of variation between countries by each year } \\
\hline Country & $\begin{array}{c}\text { Total } \\
\text { earned } \\
\text { premiums }\end{array}$ & $\begin{array}{l}\text { Total earned } \\
\text { non-life } \\
\text { premiums }\end{array}$ & $\begin{array}{l}\text { Total earned } \\
\text { life premiums }\end{array}$ & Year & $\begin{array}{l}\text { Total earned } \\
\text { premiums }\end{array}$ & $\begin{array}{c}\text { Total earned } \\
\text { non-life premiums }\end{array}$ & $\begin{array}{l}\text { Total earned } \\
\text { life premiums }\end{array}$ \\
\hline SRB & 12.0 & 11.3 & 8.9 & 2007 & 47.4 & 48.6 & 31.7 \\
\hline $\mathrm{CRO}$ & 7.8 & 9.1 & 3.3 & 2008 & 45.2 & 46.3 & 34.0 \\
\hline $\mathrm{BIH}$ & 2.0 & 1.6 & 3.3 & 2009 & 41.2 & 43.6 & 38.6 \\
\hline MNE & 28.1 & 22.0 & 18.5 & 2010 & 38.1 & 40.2 & 38.4 \\
\hline FYRM & 16.9 & 13.0 & 12.1 & 2011 & 37.3 & 39.5 & 36.2 \\
\hline ROU & 5.1 & 4.4 & 3.1 & 2012 & 34.9 & 37.7 & 32.9 \\
\hline BLG & 5.8 & 3.3 & 11.4 & & & & \\
\hline ALB & 3.7 & 3.5 & 6.9 & & & & \\
\hline
\end{tabular}

Total earned premiums

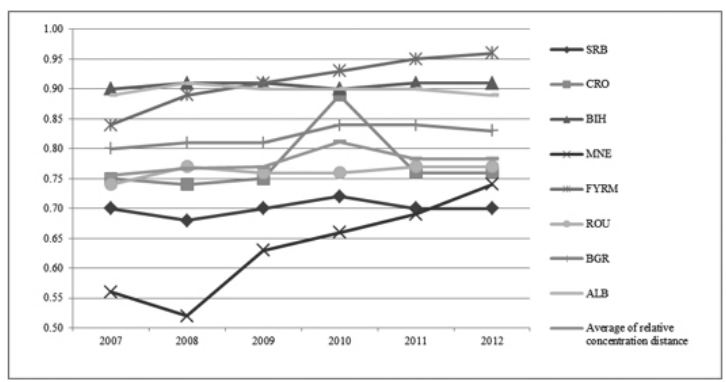

Total earned non-life premiums

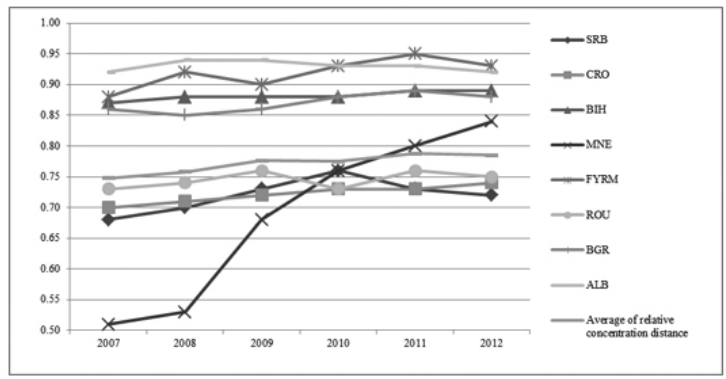

Total earned life premiums

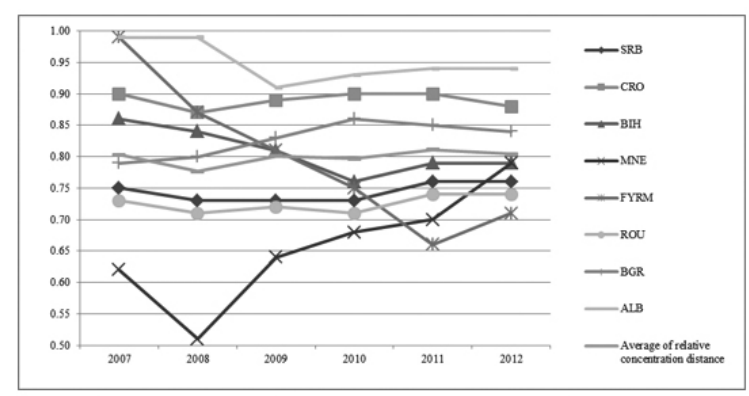

Figure 3: RE coefficient 
life insurance, taking into account the number of insurance companies in the market. Although the value of relative distance of concentration in the ALB insurance market exceed $90 \%$ (indicating equal distribution of participation in general) this segment of insurance market is underdeveloped, because there were only three insurance companies operating in life insurance during this period.

Coefficients of variation of RE illustrate that the major changes occurred between countries, with evident fluctuations according to criteria of total earned non-life premium and total earned life insurance premium in terms of the level of concentration in the insurance sector.

The highest values of the coefficient of variation of RE (according to all analysed criteria) are found in 2010. On the other hand, major changes in terms of total earned nonlife premiums criterion occurred in the insurance market in MNE (20,3\%), while the smallest oscillations are recorded in the insurance market in $\mathrm{BiH}$ and ALB (especially in total earned premium and total earned non-life premiums) in dynamic model.

Table 4: Coefficients of variation of RE (in \%)

\begin{tabular}{|c|c|c|c|c|c|c|c|}
\hline \multicolumn{4}{|c|}{$\begin{array}{l}\text { Coefficients of variation by each country in the period } \\
\qquad 2007-2012\end{array}$} & \multicolumn{4}{|c|}{ Coefficients of variation between countries by each year } \\
\hline Country & $\begin{array}{c}\text { Total } \\
\text { earned } \\
\text { premiums }\end{array}$ & $\begin{array}{c}\text { Total earned } \\
\text { non-life } \\
\text { premiums }\end{array}$ & $\begin{array}{l}\text { Total earned } \\
\text { life premiums }\end{array}$ & Year & $\begin{array}{l}\text { Total earned } \\
\text { premiums }\end{array}$ & $\begin{array}{l}\text { Total earned } \\
\text { non-life premiums }\end{array}$ & $\begin{array}{l}\text { Total earned } \\
\text { life premiums }\end{array}$ \\
\hline SRB & 1.8 & 3.8 & 2.0 & 2007 & 6.4 & 9.7 & 9.9 \\
\hline $\mathrm{CRO}$ & 7.3 & 2.0 & 1.4 & 2008 & 7.4 & 9.0 & 9.8 \\
\hline $\mathrm{BIH}$ & 0.6 & 0.9 & 4.5 & 2009 & 6.8 & 7.9 & 9.8 \\
\hline $\mathrm{MNE}$ & 12.9 & 20.3 & 14.2 & 2010 & 8.4 & 8.8 & 11.1 \\
\hline FYRM & 4.8 & 2.7 & 15.0 & 2011 & 7.3 & 8.8 & 9.2 \\
\hline ROU & 1.5 & 1.9 & 1.9 & 2012 & 7.2 & 8.6 & 7.6 \\
\hline BLG & 2.1 & 1.8 & 3.3 & & & & \\
\hline ALB & 0.8 & 1.0 & 3.5 & & & & \\
\hline
\end{tabular}

Total earned premiums

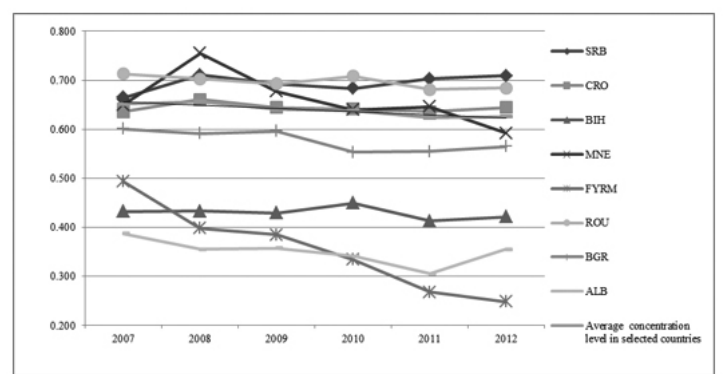

Total earned non-life premiums

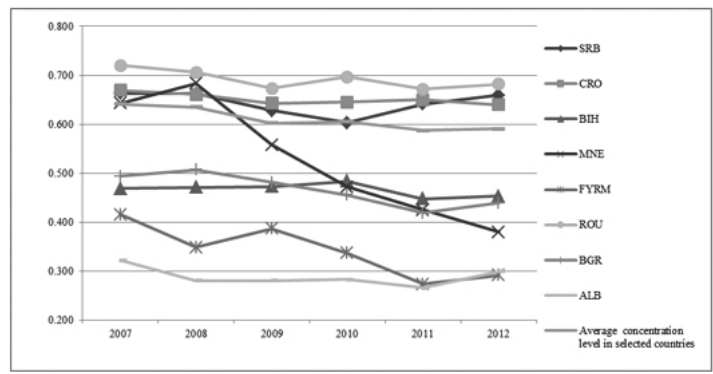

Total earned life premiums

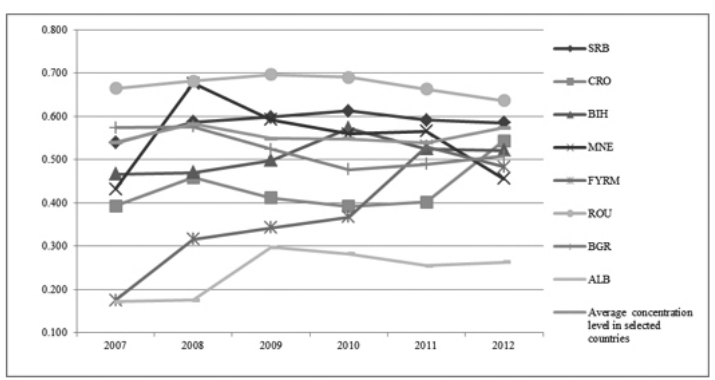

Figure 4: G coefficient 


\subsection{Gini coefficient}

Average values of $\mathrm{G}$ in insurance sector SEE countries have values around 0.6 which indicates that there are high levels of inequality of distribution of market shares between individual participants in the region.

According to total earned premiums criteria, values of $\mathrm{G}$ indicates that ALB and $\mathrm{BiH}$ are the markets with the lowest level of concentration, while ROU and SRB insurance markets values of 0.7 belong to the most concentrated markets in the region.

In terms of total earned non-life premiums criteria, $\mathrm{G}$ values of $\mathrm{BiH}, \mathrm{BGR}$ and partly MNE insurance market are about 0.5 . The lowest level of concentration was recorded on ALB insurance market (about 0.3 ), while other countries had values in the range 0.6 and 0.7 .

More significant changes were recorded in the life-insurance segment. Accordingly, the lowest concentration level was on ALB market (about 0.3); on borders of even distribution was $\mathrm{BiH}$, while the highest level of concentration was achieved in ROU (0.7).

Values of $\mathrm{G}$ variation coefficient in insurance markets shows that significant changes happened between the countries per particular years, where the highest values of variations of coefficient were recorded in terms of life-insurance premiums (above 20\%, with exception in 2008 and 2012). Accordingly, significant variations of $G$ in life-insurance premiums were recorded in FYRM (34.3\%) and ALB $(22.5 \%)$, while the lowest values were in CRO (with the exception of life-insurance premium) and ROU insurance market.

\section{Interpretation of the results}

\subsection{Testing of $\mathrm{H} 1$}

Analysis of obtained values lead to following conclusions:

1. The level of concentration and inequality in the insurance sector in the region has stagnated during this period; average values of CR4 indicates high level of concentration, especially in the segment of life insurance in all analysed countries in the same period.

2. On the other hand, the average value of HHI show that the insurance market in the region medium-concentrated, whereas with the CR4 life insurance segment stands out as the most concentrated.

3. According to the criteria of development of the total earned premium and non-life insurance premium recorded a downward trend in the average value of the level of concentration in the analysed region, which is still moving in the range of medium concentrated market.

4. In the regional insurance market, there is uneven distribution of market share which is confirmed by the average value of $\mathrm{G}$ (about 0.6 under all three analysed criteria).

5. When it comes to the average values obtained for RE in the reporting period, we can say that they are located in a zone that is closer to the relative uniformity and equality of insurance companies in the analysed period. 6 . The variations between the countries analysed in the analysed period are relatively stable.

The data in Table 6 show ranks countries according to some indicators of concentration in the insurance sector according to the criteria overall earned insurance premiums in 2007 and 2012. Rank 1 is the highest level of concentration, while rank 8 represents the lowest level of

Table 5: Coefficient variation of G (in \%)

\begin{tabular}{|c|c|c|c|c|c|c|c|}
\hline \multicolumn{4}{|c|}{$\begin{array}{l}\text { Coefficient of variations of each country in the period } \\
\qquad 2007-2012\end{array}$} & \multicolumn{4}{|c|}{ Coefficients of variation between countries by each year } \\
\hline Country & $\begin{array}{c}\text { Total } \\
\text { earned } \\
\text { premiums }\end{array}$ & $\begin{array}{l}\text { Total earned } \\
\text { non-life } \\
\text { premiums }\end{array}$ & $\begin{array}{l}\text { Total earned } \\
\text { life premiums }\end{array}$ & Year & $\begin{array}{l}\text { Total earned } \\
\text { premiums }\end{array}$ & $\begin{array}{l}\text { Total earned } \\
\text { non-life } \\
\text { premiums }\end{array}$ & $\begin{array}{l}\text { Total earned } \\
\text { life premiums }\end{array}$ \\
\hline SRB & 2.5 & 3.7 & 4.2 & 2007 & 11.0 & 15.5 & 22.9 \\
\hline $\mathrm{CRO}$ & 1.4 & 1.7 & 13.6 & 2008 & 11.9 & 15.4 & 17.8 \\
\hline $\mathrm{BIH}$ & 2.8 & 2.9 & 7.8 & 2009 & 12.1 & 15.1 & 23.1 \\
\hline MNE & 8.2 & 23.1 & 16.5 & 2010 & 14.0 & 17.8 & 24.4 \\
\hline FYRM & 25.6 & 15.8 & 34.3 & 2011 & 15.3 & 20.3 & 21.9 \\
\hline ROU & 1.9 & 2.8 & 3.3 & 2012 & 15.5 & 19.9 & 9,9 \\
\hline BLG & 3.7 & 7.3 & 8.0 & & & & \\
\hline ALB & 7.6 & 6.8 & 22.5 & & & & \\
\hline
\end{tabular}


concentration in the market. Based on these results we can conclude that the insurance market in $\mathrm{BiH}$ (where prevail Ranks 8 and 7) at least concentrated market. On the other hand, the highest concentration levels were recorded on the MNE (on which is the most rank 1) and SRB insurance market (rank 2).

The data in the table below provide an overview of changes ranks countries according to individual indicators levels of concentration in the insurance sector, using the criteria of total earned premiums in the surveyed countries in the analysed period. We can notice that in the insurance sector are present significant changes in rankings of countries according to their level of concentration. In particular, the most noticeable changes are at the G and RE, while with the other hand at least changes observed in HHI and E. Observed by countries, the largest number of changes to the ranks of some indicators of concentration was recorded in the insurance market of ALB, while on the other hand at least oscillations rankings visible on the BLG insurance market.

H1 was partially confirmed due to the fact that the results obtained in terms of CR4 suggest the existence of an average of the high level of concentration, while HHI indicates that the insurance market in the region is medium concentrated. Indicators of inequality of distribution of market shares $(\mathrm{G})$ indicate the existence of significant disparities in the distribution of market shares. The results obtained on the basis of RE indicate the fact that we can talk about a state that is closer to the relative uniformity.

This is carried out empirical analysis of concentration in the insurance sector represents the initial step for the analysis of the entire financial system in the region. Obtained levels of concentration in the insurance sector point to the current market conditions in the countries studied. The fact is that analysed the financial sector is trying to use a limited and still under-developed and regulated financial markets in the region in order to achieve higher margins. The significant fact for the insurance sector is that leaders often operate to the detriment of the insured earning higher profits. This is best seen in the case of unfavourable business conditions and underdeveloped product range when it comes to the segment of insurance, especially life. However, it isn't desirable to restrict the movement of the market leaders, but it is necessary to monitor their activities

Table 6: Ranks of the countries according to concentration indicators on insurance market in terms of total earned insurance premium

\begin{tabular}{|c|c|c|c|c|c|c|c|c|c|c|}
\hline Year & \multicolumn{9}{|c|}{2007} & \multicolumn{7}{|c|}{2012} \\
\hline Country/Indicator & CR4 & HHI & E & RE & G & CR4 & HHI & E & RE & G \\
\hline SRB & 2 & 2 & 2 & 2 & 2 & 2 & 3 & 3 & 1 & 1 \\
\hline CRO & 4 & 4 & 5 & 4 & 4 & 4 & 4 & 5 & 3 & 3 \\
\hline BIH & 8 & 8 & 8 & 8 & 7 & 7 & 8 & 8 & 7 & 6 \\
\hline MNE & 1 & 1 & 1 & 1 & 3 & 1 & 1 & 1 & 2 & 4 \\
\hline FYRM & 3 & 5 & 4 & 6 & 6 & 5 & 5 & 4 & 8 & 8 \\
\hline ROU & 7 & 7 & 7 & 3 & 1 & 6 & 7 & 7 & 4 & 2 \\
\hline BLG & 6 & 6 & 6 & 5 & 5 & 8 & 6 & 6 & 5 & 5 \\
\hline ALB & 5 & 3 & 3 & 7 & 8 & 3 & 2 & 2 & 6 & 7 \\
\hline
\end{tabular}

Table 7: Changes of concentration indicators' ranks in insurance sector in terms of total earned insurance premium comparing years 2012 with 2007

\begin{tabular}{|c|c|c|c|c|c|}
\hline $\mathbf{t}$ & $\mathbf{C R 4}$ & HHI & $\mathbf{E}$ & $\mathbf{R E}$ & $\mathbf{G}$ \\
\hline $\mathrm{SRB}$ & $=$ & +1 & -1 & +1 & -1 \\
\hline $\mathrm{CRO}$ & $=$ & $=$ & $=$ & +1 & -1 \\
\hline $\mathrm{BIH}$ & -1 & $=$ & $=$ & -1 & -1 \\
\hline $\mathrm{MNE}$ & $=$ & $=$ & $=$ & -1 & +1 \\
\hline $\mathrm{FYRM}$ & +2 & $=$ & $=$ & -2 & +2 \\
\hline $\mathrm{ROU}$ & -1 & $=$ & $=$ & +1 & +1 \\
\hline $\mathrm{BLG}$ & +2 & $=$ & $=$ & $=$ & $=$ \\
\hline ALB & -2 & -1 & +1 & +1 & -1 \\
\hline
\end{tabular}


and prevent the abuse of market position by controlling the regulatory authorities. In other words, it does not mean that the establishment of dominant positions on the market is automatically unfavoured market situation, if there is a strong state regulation that reacts to every kind of abuse of dominant position (Aćimović, 2008). In addition, we must not omit the fact that the enlargement of the capital in the financial sector leading to increased efficiency and it does not necessarily lead to an increase in the level of concentration. In addition to these criteria, there are other moments that influence the level of concentration, which were not the subject of our research (institutional barriers, geographical barriers to enter the market, the cost of replacement products, capping prices, product differentiation, and other criteria).

\subsection{Testing of $\mathrm{H} 2$}

To verify this hypothesis we use the following indicators of concentration CR4, HHI, G, E and RE. Analyses of the insurance sector begin to statistics based on criteria total earned insurance premium in the analysed group of countries in the region. The results show that in the insurance sector, it can't be claimed that the analysed concentrations indicators are correlated highly with each other. In other words, in the empirical analysis we can't rely only on individual indicators of concentration, but we need a comprehensive look at all the indicators since the concentration between the indicators there are differences in the strength of the correlation. There was a statistically significant positive correlation with the materiality threshold of 0.01 between the CR4 and HHI (0.853) and statistically significant negative correlation with the materiality threshold of 0.01 between the HHI indicators and $\mathrm{E}(0.926), \mathrm{CR} 4$ and $\mathrm{E}$ $(-0.893)$, as and $\mathrm{G}$ and RE (-0.855).

In order to have a clearer picture of the insurance market in the analysed countries in the region, it is necessary to analyse the concentration of indicators to supplement the subjective assessment of the nature of the market and the relationship between competitors on it. The insurance markets in the analysed countries in the region have several common characteristics:

1. All parameters of development (gross premiums, penetration and insurance density) indicate that the region lags behind developed countries. Historically the structure of the portfolio in the region we analysed is in the favour of non-life insurance segment.

2. When it comes to the number of participants in the insurance market in SEE countries, over the past six years have not recorded excessive fluctuations. What is unique for the region is the fact that a larger number of insurers operating in the segment of non-life insurance as a result of the lack of citizens' awareness of the importance of life insurance.

3. Prior to the adoption of the Law on Insurance, insurance market in countries in the region was characterized by unfair competition and the small number of insurance products. The harmonization of legal acts

Table 8: The Pearson correlation coefficient in the insurance sector (according to the criteria of total insurance earned premiums)

\begin{tabular}{|c|c|c|c|c|c|c|}
\hline & & CR4 & HHI & G & E & RE \\
\hline \multirow{4}{*}{ CR4 } & Pearson Correlation & 1 & $.853^{* *}$ & .168 & $-.893^{* *}$ & $-.512^{* *}$ \\
\cline { 2 - 7 } & Sig. (2-tailed) & & .000 & .254 & .000 & .000 \\
\cline { 2 - 7 } & N & 48 & 48 & 48 & 48 & 48 \\
\hline \multirow{4}{*}{ HHI } & Pearson Correlation & $.853^{* *}$ & 1 & .255 & $-.926^{* *}$ & $-.668^{* *}$ \\
\cline { 2 - 7 } & Sig. (2-tailed) & .000 & & .080 & .000 & .000 \\
\cline { 2 - 7 } G & N & 48 & 48 & 48 & 48 & 48 \\
\cline { 2 - 7 } & Pearson Correlation & .168 & .255 & 1 & -.035 & $-.855^{* *}$ \\
\cline { 2 - 7 } & Sig. (2-tailed) & .254 & .080 & & .816 & .000 \\
\hline \multirow{3}{*}{ E } & Pearson Correlation & $-.893^{* *}$ & $-.926^{* *}$ & -.035 & 1 & 48 \\
\cline { 2 - 7 } & Sig. (2-tailed) & .000 & .000 & .816 & & $.490^{* *}$ \\
\cline { 2 - 7 } & N & 48 & 48 & 48 & 48 & .000 \\
\hline \multirow{3}{*}{ RE } & Pearson Correlation & $-.512^{* *}$ & $-.668^{* *}$ & $-.855^{* *}$ & $.490^{* *}$ & 48 \\
\cline { 2 - 7 } & Sig. (2-tailed) & .000 & .000 & .000 & .000 & 1 \\
\cline { 2 - 7 } & N & 48 & 48 & 48 & 48 & 48 \\
\hline
\end{tabular}

**. Correlation is significant at the 0.01 level (2-tailed). 
with the EU member states as well as the establishment of supervisory authorities impacted the interest of foreign investors for insurance market of SEE countries.

4. The process of privatization in the region is carried out differently in the analysed countries and it is visible on the basis of the level of concentration. Thus, the countries in the region that are cautiously entered the process of transformation of ownership managed to keep the national insurers. On the other hand, countries that have allowed the privatization of national insurers with the largest market share now have about $15 \%$ share in the segment of non-life insurance (in the case of MNE and FYRM).

5. The main motive for foreign investors in this market is underserved market of insurance, provided the opportunity to develop primarily due to low insurance premiums per capita and low participation of gross premium in GDP.

6. The macroeconomic environment in which insurance companies operate is the result of how the socio-economic crisis in the countries in the region and the world financial crisis.

Unlike financial systems that have been developed and stable insurance sector (in particular segment life insurance), this part of the financial system is still under development in the analysed countries. The experience of countries with stable and strong financial sector shows that after the development of the banking sector stronger insurance sector. Based on these data we can conclude that the major changes in the level of concentration in the forthcoming period, likely in the insurance sector, particularly in the segment of life, compared with the banking sector, which has for years in the analysed region is saturated.

\subsection{Testing of $\mathrm{H} 3$}

H3 verified using the following indicators of concentration CR4, HHI, G, E and RE (which will be analysed on the basis of total insurance earned premiums), which are placed in a relationship with an indicator of economic development (GDP pc). H3 will be verified by application of Spearmen's correlation coefficient in 2007 and in 2012. The following table provides an overview of GDP pc in the analysed countries in 2007 and 2012, ranks countries as well as indices of development of countries (least developed country $=100$ ). Based on the data we can notice that ALB had the lowest level of economic development (index of 100); while CRO recorded the highest level of GDPpc (index 372 in 2007 and 300 in 2012).

Validity of $\mathrm{H} 3$ is continued by analysing the insurance sector in selected countries in the region, based on the criteria the total earned insurance premiums in 2007 and 2012.

The obtained results of Spearmen's correlation coefficient confirm H3 i.e. the level of concentration of poorly correlated with the level of economic development as it is in all cases (except $\mathrm{G}$ in 2007, which was the only statistically significantly correlated with GDP pc) recorded correlations that are in the zone of lower value. It can be concluded that the analysed countries are on relatively similar level of development but they have significantly different levels of concentration in the insurance sector. Although at different levels of development, some countries had similar levels of concentration.

In the first case, when we talk about relatively similar levels of development and different level of concentration we can take for example the insurance market (measured by the criterion of total earned insurance premiums) in $\mathrm{BiH}$ and ALB. Whereas in these two countries in 2012 measured nearly identical GDP pc recorded significant differences in the level of concentration. In the case of CR4 in $\mathrm{BiH}$ had a value of $38 \%$, while in the ALB was as much as $68 \%$. In addition, $\mathrm{HHI}$ insurance market in $\mathrm{BiH}$ catego-

Table 9: GDP pc (in USD), rank and index in 2007 and 2012. Source: World Bank, authors' calculation

\begin{tabular}{|c|c|c|c|c|c|c|}
\hline & $\mathbf{2 0 0 7}$ & Rank & $\begin{array}{c}\text { Index (the least developed } \\
\text { country =100) }\end{array}$ & $\mathbf{2 0 1 2}$ & Rang & $\begin{array}{c}\text { Index (the least developed } \\
\text { country =100) }\end{array}$ \\
\hline SRB & 5.458 & 5 & 150 & 5.666 & 5 & 129 \\
\hline CRO & 13.540 & 1 & 372 & 13.235 & 1 & 300 \\
\hline BIH & 3.991 & 6 & 110 & 4.410 & 7 & 100 \\
\hline MNE & 5.946 & 3 & 163 & 6.514 & 4 & 148 \\
\hline FYRM & 3.892 & 7 & 107 & 4.548 & 6 & 103 \\
\hline ROU & 8.170 & 2 & 225 & 8.437 & 2 & 191 \\
\hline BLG & 5.783 & 4 & 159 & 7.198 & 3 & 163 \\
\hline ALB & 3.639 & 8 & 100 & 4.406 & 8 & 100 \\
\hline
\end{tabular}


Table 10: Spearman's correlation coefficient between the concentration ratios in the insurance sector (according to the criteria of total earned insurance premiums) and GDP pc

*. Correlation is significant at the 0.05 level (2-tailed)

\begin{tabular}{|c|c|c|c|c|c|}
\hline \multicolumn{3}{|c|}{2007} & \multicolumn{3}{|c|}{2012} \\
\hline \multicolumn{3}{|c|}{ GDPpc } & \multicolumn{3}{|c|}{ GDPpc } \\
\hline \multirow{3}{*}{ CR4 } & Correlation Coefficient & .048 & \multirow{3}{*}{ CR4 } & Correlation Coefficient & -.119 \\
\hline & Sig. (2-tailed) & .911 & & Sig. (2-tailed) & .779 \\
\hline & $\mathrm{N}$ & 8 & & $\mathrm{~N}$ & 8 \\
\hline \multirow{3}{*}{ HHI } & Correlation Coefficient & .000 & \multirow{3}{*}{ HHI } & Correlation Coefficient & -.119 \\
\hline & Sig. (2-tailed) & 1.000 & & Sig. (2-tailed) & .779 \\
\hline & $\mathrm{N}$ & 8 & & $\mathrm{~N}$ & 8 \\
\hline \multirow{3}{*}{ G } & Correlation Coefficient & $.738^{*}$ & \multirow{3}{*}{ G } & Correlation Coefficient & .643 \\
\hline & Sig. (2-tailed) & .037 & & Sig. (2-tailed) & .086 \\
\hline & $\mathrm{N}$ & 8 & & $\mathrm{~N}$ & 8 \\
\hline \multirow{3}{*}{ E } & Correlation Coefficient & .143 & \multirow{3}{*}{$\mathrm{E}$} & Correlation Coefficient & .238 \\
\hline & Sig. (2-tailed) & .736 & & Sig. (2-tailed) & .570 \\
\hline & $\mathrm{N}$ & 8 & & $\mathrm{~N}$ & 8 \\
\hline \multirow{3}{*}{$\mathrm{RE}$} & Correlation Coefficient & -.643 & \multirow{3}{*}{$\mathrm{RE}$} & Correlation Coefficient & -.524 \\
\hline & Sig. (2-tailed) & .086 & & Sig. (2-tailed) & .183 \\
\hline & $\mathrm{N}$ & 8 & & $\mathrm{~N}$ & 8 \\
\hline
\end{tabular}

rized as poor are concentrated (with 640 points), while it cannot be said of the insurance market in the ALB in which the measured concentration of 1,640 points.

In the second case, we are talking about countries with different levels of development that have similar levels of concentration, we can analyse CRO and FYRM insurance market in 2012. Statistical data show that in 2012 CRO was economically significantly more developed than FYRM (ratio 2.9 GDP pc : 1). However, the concentration ratio values obtained show that in the countries analysed recorded a similar level of concentration. So CR4 shows values of $51 \%$ and $60 \%$ FYRM the CRO, while HHI values for medium-concentrated market $(1,000$ and 1,300 in FYRM and CRO, respectively).

\section{Conclusion}

Based on the conducted empirical research the authors came to the following conclusions:

- CR4 indicates a high level of average concentrations of all analysed criteria of development of the insurance sector.

- HHI indicates that the regional insurance market is medium concentrated, except in the case of life insurance, which belongs to the group highly-concentrated markets.

- Regional insurance sector is characterized by a high degree of unevenness in the distribution of market shares between individual participants ( $\mathrm{G}$ values).

- RE values are located in a zone that is closer to the relative uniformity and equity businesses.

- The average level of concentration and inequality in regional insurance sector stagnated during this period.

- The insurance market in BiH, ROU and BLG is the least concentrated market, while highly concentrated markets are SRB and MNE.

- In the regional insurance sector are present significant changes of countries' ranks according to the level of concentration in the region. In particular, the most noticeable changes are at $\mathrm{G}$ and $\mathrm{RE}$, while with the other hand at least changes observed in HHI and $\mathrm{E}$. Observed by countries, the largest number of changes to the ranks of some indicators of concentration was recorded in ALB insurance market, while on the other hand at least oscillations rankings visible in BLG insurance market.

- The results showed that the analysed concentration indicators in the insurance sector confirmed that there were differences in the level of correlation and therefore, in order to gain a realistic idea about the state of the level of concentration and forecast future movements necessary integral observation and analysis of several indicators of concentration, thus avoiding the adoption of conclusions only on the basis of a forward movement of chosen concentration indicator. 
- In all observed indicators of concentration in relation with the density level GDP pc move in the zone of very low value, which on the one hand points to the fact that the analysed countries at a relatively similar level of development have significantly different levels of concentration, but also on the fact that some countries although at different levels of development, have similar levels of concentration.

Future research will cover a longer period of time until the end of 2016, to determine whether the same findings could be applied in the future, or that you will appear in the insurance market by competitors from other industries that would significantly change the picture of concentration, or quality and sophistication of insurance products.

\section{References}

Aćimović, S. (2008). Dominant Positions in the Market-Problem or Not? In Drašković, B., Vuković, V. (eds.). Market Structure and Competitiveness Protection, Experiences from the Transition Countries, Belgrade, Institute of Economic Sciences, pp. 33-45.

Albanian Financial Supervisory Authority (2007-2012). Insurance Geography Statistical Report (2007-2012). Retrieved from: http://www.amf.gov.al/statistika.as$\mathrm{p} ? \mathrm{id}=1 \& \mathrm{~s}=1$

Athanasoglou, P.P., Delis, M.D., \& Staikouras C.K. (2006). Determinants of Bank Profitability in the South eastern European Region. Bank of Greece, Working paper No. 47.

Beck T., Demirgüç-Kunt A, Levine R. (2003). Bank concentration and crises, NBER working paper No. 9921.

Bikker, J.A., \& Haff, K. (2000). Measures of Competition and Concentration in the Banking Industry: a Review of a Literature. De Nederlandsche Bank, Research series supervision No. 27.

Bikker J.A., \& Haff K. (2001). Competition, concentration and their relationship: An empirical analysis of the banking industry, DNB staff report No.68, De Nederlandische Bank.

Chamberlain E. (1929). Duopoly: Value where sellers are few, Quarterly Journal of Economics, 43, pp. 63-100.

Croatian insurance bureau (2007-2012). Insurance market in the Republic of Croatia (2007-2012). Retrieved from: https://www.huo.hr/eng/publications/50/

Ćurak, M., Poposki, K., \& Pepur, S. (2012). Profitability Determinants of the Macedonian Banking Sector in Changing Environment. Procedia - Social and Behavioral Sciences, 44, pp. 406-416, https://doi. org/10.1016/j.sbspro.2012.05.045

Dimić M. (2015). Analysis of concentration level in banking and insurance sector in SEE countries, $\mathrm{PhD}$ dissertation, Singidunum University, Belgrade

Dimić M., Barjaktarović L. (2017). Ownership transformation of the banking sector in SEE countries,
Bankarstvo Journal, Vol. 46, No.1, pp.84-103.

Dumićić, K., Pavković, A., \& Akalović-Antić, J. (2012). Measuring the concentration in banking in the Republic of Croatia, Proceeding of the Faculty of Economics and Business in Zagreb, 10(2), pp. 117-136.

Financial Supervision Commission in Bulgaria (20072012). Statistics for the Non-life and Life Insurance Companies (2007-2012). Retrieved from: http://www. fsc.bg/en/markets/insurance-market/statistics/

Hall, M. \& Tideman, N. (1967). Measures of Concentration. Journal of the American Statistical Association, 62, pp. 162-168, http://dx.doi.org/10.2307/2282919

Hall R. \& Hitch C. (1999). Price theory and business behavior, Oxford Economic papers, 2, pp. 12-145.

Hawkins, J., \& Mihaljek, D. (2001). The Banking Industry in the Emerging Market Economies: Competition, Consolidation and Systemic Stability, BIS Paper No.4. Retrieved from: http://www.bis.org/publ/bppdf/bispap04a.pdf

Insurance Agency of $\mathrm{BiH}$ (2007-2012). BiH Insurance Market Statistics (2007-2012). Retrieved from: http:// www.azobih.gov.ba/cms/index.php?option=com_content\&task $=$ view\&id $=92 \&$ Itemid $=71$

Insurance Europe (2014). European Insurance in Figures (Januar-Februar 2014). Retrieved from: http://www. insuranceeurope.eu/search/type/Publication.

Insurance Information Institute (2010-2011, 2013-2014). International Insurance Fact Book (2010-2011, 20132014). Retrieved from: http://www.iii.org/publications

Insurance Supervision Agency of Montenegro (20072012). Report on Insurance Market in Montenegro (2007-2012). Retrieved from: http://www.ano.me/en/ index.php?option $=$ com_phocadownload\&view $=$ category\&id $=2: \&$ Itemid $=69$

Insurance Supervision Agency Republic of Macedonia (2009-2012). Report on the Scope and Content of the Insurance Operations (2009-2012). Retrieved from: http://www.aso.mk/index.php?option=com_fjrelated\&view $=$ fjrelated $\&$ id $=0 \&$ Itemid $=91 \&$ lang $=$ en

International Monetary Fund (IMF) (2010, 2013). World Economic Outlook (2010, 2013). Retrieved from: http://www.imf.org/external/pubs/ft/weo/2013/02/

Kostić, M. (2008). Measurement of Industrial Supply Concentration. Economic Horizons, 10 (1), pp. 89-108. Retrieved from: http://www.horizonti.ekfak.kg.ac.rs/ sites/default/files/Casopis/2007/6_Milan_Kostic.pdf

Kraft E. (2007). What is the level of concentration in the banking sector of Croatia? Retrieved from http://www. hnb.hr/publikac/istrazivanja/i-019.pdf

Kundid, A., Škrbić, B., \&, Ercegovac, R. (2011). Determinants of Bank Profitability in Croatia. Croatian $O p$ erational Research Review (CRORR), 2, pp. 168-182.

Lipczynski, J., \& Wilson, J. (2001). Industrial Organisation- an Analysis for Compatitive Markets. Harlow: Prentice Hall.

Ljubaj, I. (2005). Concentration Indicators of Banking Sector in the Republic of Croatia. Croatian National Bank. 
Marinković, S. (2007). The Industrial Concentration in Serbian Banking: The Degree and its Dynamics. Economic Themes, 31(2), 283-299. Retrieved from: http:// teme2.junis.ni.ac.rs/public/journals/1/previousissues/ teme2-2007/teme2-2007-06.pdf

Martin, S. (2002). Advanced Industrial Economics. Oxford, UK: Blackwell Publishers Ltd.

Mc Conell, C.R., \& Brue, S.L. (1996). MicroeconomicsPrinciples, Problems and Policies. London: McGraw Hill Inc.

Miljković M., Filipović S. \& Tanasković S. (2013). Market concentration in the banking sector - Evidence from Serbia, Industrija, 41 (2), 7-25.

National Bank of Serbia (2007-2012). Insurance Supervision, Insurance Sector Reports (2007-2012). Retrieved from: http://www.nbs.rs/internet/english/60/60_6/index.html

National Bank of Serbia (2016). Insurance Supervision, Insurance Companies Operations, Total Insurance Premium by Insurance Companies and Types of Insurance. Retrieved from: http://www.nbs.rs/internet/english/60/60_2/index.html

Njegomir, V., \& Stojić, D. (2011). Liberalisation and Market Concentration Impact on Performance of the Nonlife Insurance Industry: The Evidence from Eastern Europe, The International Association for the Study of Insurance Economics 1018-5895/11, The Geneva Papers. 36 (1), pp. 94- 106, http://dx.doi.org/10.1057/ gpp. 2010.32

Organization for Economic Co-operation and Development (OECD) (2011). The Impact of the Financial Crisis on the Insurance Sector and Policy Responses. Retrieved from: http://www.oecd.org/daf/ca/corporategovernanceprinciples/theimpactofthefinancialcrisisontheinsurancesectorandpolicyresponses.htm

Romanian Insurance Supervisory Commission (2012). Report on the Romanian Insurance Market and the Insurance Supervision in 2012. Retrieved from: http:// asfromania.ro/en/

Stojanović, B., Stanišić, T., \& Veličković, M. (2010). Problem zaštite konkurencije u trgovini na malo u Srbiji. Škola biznisa, 3, pp. 57-66. Retrieved from: http:// www.vps.ns.ac.rs/SB/2010/3.7.pdf

Swiss Re, Sigma (2007-2012). Insurance Research. World Insurance. Retrieved from: http://institute.swissre. com/research/overview/.

Sweezy P. (1939). Demand under conditions of oligopoly, Journal of Political Economy. 47, pp. 468-473, https:// doi.org/10.1086/255420

Šubić, R. (2009). Role of Foreign Banks in Integration of Banking Industry. Economic Journal, 22(2), pp. 296313.

Zingales L., Raghuram R. (2003). Banks and Markets: The Changing Character of European Finance, NBER Working Paper No. 9595
Maja Dimić is an Assistant Professor at the Faculty of Business Studies and Law, University Union Nikola Tesla in Belgrade. Her major research interests concern economics, finance, insurance and banking sector. She teaches on undergraduate, master and doctoral level. She is author of chapters in books and articles in scientific and professional journals, published in Serbia and abroad.

Lidija Barjaktarović has a PhD in Economic Sciences in sectors banking and finance. At the University Singidunum in Belgrade she teaches Banking, Risk Management and Corporate Finances (from 2008). She has been Head of master study programs Business Economics and Public Sector Management at Singidunum University since 2014. She had banking career in the period from 1998 to 2008. It started in Jugobanka A.D. Belgrade, after which she moved to Societe General Yugoslav Bank a.d. Belgrade, and then to Raiffeisen Bank a.d. Belgrade in order to be promoted to the Head of the Regional Branch Central Serbia. In 2005 she moves to Erste Bank a.d. Novi Sad to become the Director of Corporate Division. At the end of 2007 Erste Group names her to be a member of the Corporate Board and Corporate Working Group on the level of the Erste Holding Vienna.

Olja Arsenijević, is full professor at the Faculty of Business Studies and Law in Belgrade »Union Nikola Tesla« University. Her major research interests concern management, education, marketing and safety issues. She has published several monographs, several research papers in domestic and international journals and presented her research work at many national and international conferences.

Polona Šprajc is an Associate Professor at the Faculty of Organizational Sciences, University of Maribor. Her main research interests are human resource management, marketing and business ethics.

Janez Žirovnik, master of law sciences and doctoral candidate, is a judge of the civil department of the district court in Maribor. He is also a senior lecturer at the Faculty of Logistics of University of Maribor and participates in the research and pedagogical process at the Faculty of Organisational Sciences University of Maribor in the areas of business and commercial law and crisis management. 